\title{
Covid-19 Pandemisi Sırasında Üniversite Öğrencilerinin Fiziksel Aktivite, Depresyon, Stres, Uyku ve Yaşam Kalitesi Düzeylerinin İncelenmesi
}

Investigation of Physical Activity, Depression, Stress, Sleep and Quality of Life Levels of University Students During the COVID-19 Pandemic

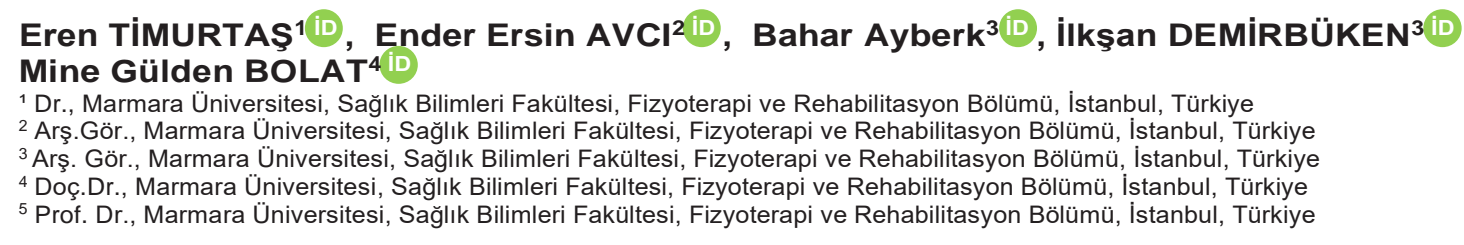

ÖZ

Amaç: Çalışmamızın amacı Covid-19 döneminde üniversite öğrencilerinin fiziksel aktivite, stres, depresyon ve uyku düzeylerinin, yaşam kalitesi ile ilişkisini araştırmaktı. Gereç ve Yöntem: Çalışmaya yaş ortalaması $20,5 \pm 1,4$ yıl, boy ortalaması $166,9 \pm 8,0 \mathrm{~cm}$, vücut kitle indeksi (VKI) $21,4 \pm 3,0 \mathrm{~kg} / \mathrm{cm} 2$ olan 273 gönüllü katılımcı (229 kadın, 44 erkek) dahil oldu. Katılımcıların fiziksel aktivite seviyeleri, Uluslararası Fiziksel Aktivite Anketi; stres düzeyleri, Algılanan Stres Ölçeği; depresyon şiddetleri, Beck Depresyon Ölçeği; uyku patern ve kaliteleri, Pittsburg Uyku Kalitesi İndeksi; yaşam kalitesi değerlendirilmesinde Dünya Sağlık Örgütü 5 İyilik Hali İndeksi (DSÖ-5) kullanıldı. İstatistiksel yöntemler olarak frekans, karşılaştırma ve regresyon analizleri kullanıldı. Sonuçlar: Katılımcıların \%52,7'si fiziksel olarak inaktifti ve \%42,5'inin fiziksel aktivite düzeyleri düşüktü. Yaklaşık \%75'inin uyku kaliteleri iyi, \%80 'inin stres algıları orta düzeydeydi. Katılımcıların yaklaşık \%66'sı minimal ve hafif düzeyde depresyona sahipti. Katılımcıların \%57,7'si kötü yaşam kalitesi sonuçları bildirdi. Fiziksel aktivite, depresyon, uyku kalitesi ve stres düzeylerinin yaşam kalitesine ilişkin çoklu regresyon analizi modeli anlamlı bulundu $(F=18,115$; $p=0,001 ; R 2=0,213)$. Tartışma: Covid-19 pandemi sürecinde üniversite öğrencilerinin fiziksel aktivite, uyku kalitesi, depresyon ve stres algılarının yaşam kalitesini etkilediği ve bu etkilerin yönetilmesinde sonuçların göz önünde bulundurulması gerektiğini önermekteyiz.

Anahtar Kelimeler: Yaşam Kalitesi; Pandemik; Egzersiz.

\section{ABSTRACT}

Purpose: Our study aimed to investigate the relationship between quality of life and physical activity, stress, depression and sleep quality among university students during the Covid-19 period. Material and Methods: A total of 273 participants (mean age: $20.5 \pm 1.4$ years; mean height: $166.9 \pm 8.0 \mathrm{~cm}$; BMl:21.4 $\pm 3.0 \mathrm{~kg} / \mathrm{cm} 2)$ were included in the study. To assess physical activity, perceived stress, depression severity, sleep quality and quality of life of the participants, the International Physical Activity Questionnaire, the Perceived Stress Scale, the Beck Depression Scale, the Pittsburg Sleep Quality Index, the WHO-5 Wellness Index were used, respectively. Frequency, comparisons and regression analysis were used as statistical methods. Results: $52.7 \%$ of the participants were physically inactive and $42.5 \%$ had low physical activity levels. About $75 \%$ had good sleep quality and $80 \%$ had a moderate perception of stress. Approximately $66 \%$ of the participants had minimal to mild depression. $57.7 \%$ of the participants reported poor quality of life. Multiple regression analysis on quality of life of physical activity, depression, sleep quality and stress levels were found significant $(F=18.115 ; p=0.001 ; R 2=0.213)$. Discussion: We suggest that physical activity, sleep quality, depression and stress affect the quality of life of students during the Covid-19 pandemic and the results should be considered in the management of these effects.

Keywords: Quality of Life; Pandemics; Exercise. 
Sağlık ile ilişkili yaşam kalitesi, genel yaşam kalitesinin fiziksel veya psikolojik sağlığı etkileyen tüm yönlerini kapsayacak şekilde geliştirilmiş genel bir kavramdır. Bu kavram kişilerin sağlık koşulları, riskleri ve fonksiyonel durumları da dahil olmak üzere fiziksel ve psikolojik sağlık ile ilişkili algılarını içermektedir. Yaşam kalitesinin değerlendirilmesinin önemi birçok nicel sağlık ölçütünden daha güçlü bir mortalite ve morbidite belirteci olmasıdır (DeSalvo, Bloser, Reynolds ve ark., 2006). Dolayısıyla, sağlığı etkileyen olumsuz koşulların yaşam kalitesini etkilenmesi kaçınılmazdır.

Tüm dünyayı etkisi altına alan koronavirüs (Covid-19) pandemisi 2020 yılı itibari ile ülkelerin gündemindedir. Dünya Sağlık Örgütü (DSÖ) tarafından pandemi olarak ilan edildikten sonra küresel düzeyde hem bireysel hem de toplumsal önlemlere ve sorumluluklara neden olmuştur. Toplum içinde bulaşı önlemek ve vaka sayılarını kontrol altına almak için çeşitli kısıtlamalara başvurulmuştur. Sosyal izolasyon, sokağa çıkma saati kısıtlılıkları, hafta sonu yasakları, restoran, kafeterya, spor salonları vb. sosyal alanların kapatılması gibi önlemlerin alınmasının yanı sıra iş ve eğitim hayatında da düzenlemeler yapılarak evden çalışma ve online eğitim dönemine geçilmiştir. Dahası, Covid-19 hastalığının sekonder sağlık problemlerine ve hatta ölümlere yol açması sebebiyle bazı kişiler, bireysel olarak tedbirlerini artırırken, 65 yaş üstü ve 20 yaş altı popülasyonlara özel olarak politika yapıcılar tarafından ek kısıtlılıklar getirilmiştir (Huang, Wang, Li ve ark., 2020; Tobaiqy, Qashqary, AlDahery ve ark., 2020). Günlük hayatı dramatik bir şekilde etkileyen bu süreç hem fiziksel hem de mental sağlık bileşenleri üzerinde olumsuz etki göstermiştir (Salari ve ark., 2020; Violant-Holz ve ark., 2020).

Sağlığın ve iyi olma halinin yapı taşlarından olan fiziksel aktivite endorfin üretimini uyararak ruh halini iyileştirir ve adrenalin ve kortizol gibi stres hormonlarının seviyesini azaltır (Pace, 2000). Fiziksel aktivitenin stres kontrolüne yardımcı olmasının yanı sıra, kardiyovasküler ve muskuloskeletal performansı arttırma, kilo kontrolü, düzenli uyku gibi ek faydalar sağlayarak kişilerin sağlık ile ilişkili yaşam kalitesini artırıcı birçok pozitif sağlık faydası sağladığı bilinmektedir (Ellis, Dumas ve Forbes, 2020; Stanton, To, Khalesi ve ark., 2020). Covid-19 sürecinde sosyal izolasyon, evden çalışma, online eğitim gibi değişiklikler sedanter zamanın artmasına ve fiziksel aktivitenin azalmasına neden olmuştur (Moriarty, Bourbeau, Fontana ve ark., 2021).

Pandemi sırasında hastalığın kendi seyrinin yanı sıra fiziksel aktiviteyi olumsuz etkileyen şartların da kişilerde stres algısı ve depresyon gibi psikolojik yükü etkileyen sağlık bileşenlerini olumsuz etkilediği bilinmektedir (Salari ve ark., 2020). Pandemi sürecinde genç yetişkinlerin, yetişkin popülasyona göre daha yüksek stres seviyesine sahip olduğu raporlanmıştır. Kısıtlama tedbirleri kapsamında üniversite kampüslerinin kapatılarak online eğitime geçilmesi pandeminin diğer yıkıcı etkileriyle birleşince genç yetişkin popülasyonunda algılanan stres ve depresyon düzeylerini artırmış olabileceği düşünülmektedir (Rogowska, Kusnierz ve Bokszczanin, 2020).

Stresli durumlarla karşı karşıya kalmak uykunun baskılanması, uyanıklığın artması gibi semptomlara neden olarak uyku kalitesi düzeyini azaltabilir (Lipert, Kozlowski, Timler ve ark., 2021). Oysaki uyku mental ve fiziksel sağlığın sürdürülmesi için oldukça önemli bir fizyolojik süreçtir. Üniversite öğrencilerinde yapılan çalışmalarda uyku kalitesinin artırılması ile mental sağlık, fiziksel aktivite düzeyi ve yaşam kalitesi arasında anlamlı ilişki bulunmuştur (Rogowska, Povlova, Kuśnierz ve ark., 2020; İyigün ve ark., 2017).

Ülkemizde Covid-19 pandemisinin ve alınan önlemlerin, bu süreçten ciddi olarak etkilenen demografik gruplardan biri olan genç yetişkinlerin sağlıklı yaşam davranışları üzerindeki etkilerine yönelik çalışmalar kısıtlıdır (Bulguroğlu ve ark., 2021; Koca ve Fazlıoğluları, 2021; Erdoğan Yüce ve Muz, 2021). Ayrıca, pandemi sırasında fiziksel aktivite, kaliteli uyku, düşük stres ve depresyon seviyelerinin genç yetişkinlerin yaşam kalitesi üzerindeki etkilerini inceleyen araştırmalara hala intiyaç duyulmaktadır. Covid-19 pandemisi sırasında genç yetişkinlerin genel sağlık durumlarının daha ayrıntılı araştırıması, bu popülasyonun esenliğine yönelik stratejilerin artırılmasına yardımcı olabilir. Bu nedenle bu çalışma ile Covid-19 döneminde üniversite öğrencilerinin fiziksel aktivite, stres, depresyon ve uyku düzeylerinin, yaşam kalitesi ile ilişkisini araştırmak amaçlandı.

\section{GEREÇ VE YÖNTEM}

Araştırmanın Tipi, Yeri ve Zamanı: Bu çalışma kesitsel tipte tasarlandı. Araştırma Eylül 2021-Aralık 2021 tarihleri arasında Marmara Üniversitesi, Sağlık Bilimleri Fakültesi, Fizyoterapi ve Rehabilitasyon Bölümü öğrencilerine e-posta ve sosyal medya aracılığıyla çevrimiçi ulaşılarak online anketler kullanılarak gerçekleştirildi. Araştırma öncesinde, tüm katılımcılardan online olarak onam alındı. 
Araştırmanın Evreni, Örneklemi, Dahil Edilme Kriterleri: Araştırmanın evreni Türkiye'de öğrenim gören genç yetişkinler olarak belirlendi. Araştırmanın örneklemi ise kolayda örneklem metodu tercih edilerek, Marmara Üniversitesi, Sağlık Bilimleri Fakültesi, Fizyoterapi ve Rehabilitasyon Bölümü'nde öğrenim gören ve çevrimiçi şekilde ulaşılabilen genç yetişkinler ile oluşturuldu. Araştırmaya fiziksel aktiviteyi engelleyecek problemi olmayan veya tanısı konmuş bir psikiyatrik hastalığı veya uyku bozukluğu olmayan gönüllü öğrenciler dahil edildi. Fiziksel aktivite alışkanlığına etki edebilecek, kalp ve solunum problemlerinin olması, kas iskelet problemlerinin varlığı, diabetes mellitus hastalığının olması, kronik ilaç kullanımı (son 3 aydır devam eden oral kontraseptif tedavi gibi), vücut kitle indeksinin $35 \mathrm{~kg} / \mathrm{m} 2$ ve üzerinde olması ve bunun dışında fiziksel aktiviteyi engelleyecek başka herhangi bir durumun varlığı ile hekim tarafından tanısı konulmuş bir psikiyatrik hastalık veya uyku bozukluğu olan öğrenciler çalışmaya dahil edilmedi.

Çalışmanın güç analizi, Fazeli, Zeidi, Lin ve arkadaşlarının 2020 yııında gerçekleştirdikleri araştırma referans alınarak G-Power 3 programı ile yapıldı. Değişkenlerin ilişkisinin belirlenmesinde 4 bağımsız değişken ve R2>0.3, $\% 80$ güç, a error prob:0,05 ve 0.40-0.56 güven aralığında örneklem büyüklüğü 250 olarak belirlendi (Fazeli ve ark., 2020).

\section{Veri Toplama Araçları}

Demografik Bilgi Formu: Araştırmacılar tarafından hazırlanan demografik bilgi formu cinsiyet, yaş, boy, kronik hastalık varlığı, kronik ilaç kullanımı ile hekim tarafından tanısı konmuş bir psikiyatrik hastalık veya uyku bozukluğu varlığı hakkında bilgi toplamak için sorulardan oluşturuldu.

Uluslararası Fiziksel Aktivite Anketi - Kısa Form: Öğrencilerin fiziksel aktivite seviyeleri, Uluslararası Fiziksel Aktivite Anketi - Kısa Form (UFAA-KF) kullanılarak belirlendi. Türkçe geçerlilik ve güvenilirlik araştırması gerçekleştirilmiş olan bu anket son yedi gündeki aktiviteleri içeren 7 sorudan oluşmaktadır (Öztürk, 2005). Kendi kendine uygulanabilir olan bu ölçeğin maddeleri üç farklı yoğunluk aralığında fiziksel aktivitenin sıklığını ve süresini değerlendiren maddeler içerir. Anket sonucunda dakika, gün ve metabolik eşdeğer (MET) değeri çarpılmış "METdakika/hafta" cinsinden bir skor elde edildi. Yürüme skorunun hesaplanmasında dakika cinsinden yürüme süresi $3.3 \mathrm{MET}$ ile çarpıldı. Orta düzeyde şiddetli aktivite için $4 \mathrm{MET}$, şiddetli aktivite için 8 MET değeri alındı. Katılımcıların fiziksel aktivite düzeyleri fiziksel olarak aktif olmayan (<600 MET$\mathrm{dk} / \mathrm{hafta})$, fiziksel aktivite düzeyi düşük (600- 3000 MET-dk/hafta) ve fiziksel aktivite düzeyi yeterli olan (>3000 MET-dk/hafta) şeklinde sınıflandırıldı (Craig, Marshall, Sjostorm ve ark., 2003).

Algılanan Stres Ölçeği: Öğrencilerin stres düzeyleri Algılanan Stres Ölçeği (ASÖ) kullanılarak incelendi. Ölçeğin kısa formları da bulunmaktadır ancak bu çalışmada 14 maddelik form kullanıldı. Beşli likert tipinde derecelendirilen ölçek ile, maddelerin toplamından elde edilen skor katılımcıların algılanan stres düzeyini belirlemekle birlikte, bu ölçekten alınabilecek maksimum puan 56 'dır. Türkçe geçerlilik ve güvenilirlik çalışması gerçekleştirilmiş olan ölçeğin değerlendirilmesinde 11-26 puan arası düşük stres düzeyini, 27-41 arası orta stres düzeyini, 42-56 arası yüksek stres düzeyini ifade etmektedir (Cohen, Kamarck ve Mermelstein, 1983; Eskin, Harlak, Demirkıran ve ark., 2013).

Beck Depresyon Ölçeği: Öğrencilerin depresyon şiddetleri Beck Depresyon Ölçeği (BDÖ) kullanılarak belirlendi. Çoktan seçmeli 21 sorudan oluşan bu ölçekte yer alan her bir sorudan alınabilecek en düşük puan 0'ken en yüksek puan 3'tür. Katılımcılardan tüm cevaplar toplanarak toplam skor elde edilmektedir. Değerlendirmede 0-9 puan arası minimal düzeyde, 1016 arası hafif düzeyde, $17-29$ arası orta düzeyde, 3063 puan arası şiddetli düzeyde depresif belirtileri ifade etmektedir. Türkçe geçerlilik ve güvenilirlik çalışması bulunan ölçekte, katılımcıların 17 ve üzeri puan alması depresyon varlığını göstermektedir (Beck, Ward, Mendelson ve ark., 1961; Hisli, 1989).

Pittsburg Uyku Kalitesi Indeksi: Öğrencilerin uyku patern ve kaliteleri Pittsburg Uyku Kalitesi İndeksi (PUKI) kullanılarak değerlendirildi. Bu indeks uyku kalitesini "kötü" ve "iyi" olarak yedi farklı bileşeni ölçerek ayırt eder. Bu bileşenler: sübjektif uyku kalitesi, uyku gecikmesi, uyku süresi, alışımış uyku etkinliği, uyku bozukluğu, ilacı kullanımı ve gündüz işlev bozukluğudur. Bu yedi bileşenden alınan puanın toplamı, toplam PUKI skorunu oluşturmaktadır. Türkçe geçerlilik ve güvenilirlik çalışması bulunan ölçekte, toplam PUKİ skorunun 5 ve 5 'ten küçük olması "iyi uyku kalitesi"ni gösterirken, 5 'ten yüksek olması 'kötü uyku kalitesi"ni göstermektedir (Buysse, Reynolds, Monk ve ark., 1989; Agargun, 1996).

Dünya Sağlık Örgütü-5 lyilik Hali Endeksi: Öğrencilerin iyilik halinin değerlendirilmesinde Dünya Sağlık Örgütü Mental Sağlık Departmanı tarafından geliştirilmiş olan Dünya Sağlık Örgütü 5 İyilik Hali İndeksi (DSÖ-5) kullanıldı. Ölçekte bulunan 5 maddeden elde edilen 
sayılar toplanarak ham puan hesaplandı. Ham puan 0-25 aralığındadır. Olası en kötü yaşam kalitesi 0'ken, 25 olası en iyi yaşam kalitesini temsil etmektedir. Ölçekte, on üç puanın altındaki bir skor veya 5 sorudan herhangi birine 0 veya 1 yanıtının verilmiş olması kötü yaşam kalitesini işaret etmektedir (Eser, Çevik, Baydur ve ark., 2019).

\section{İstatistiksel Analiz}

Çalışmanın tüm istatistiksel analizleri için SPSS (Statistical Package for Social Sciences) Windows v25.0 (SPSS Inc, IBM Corp, Armonk, New York) kullanıldı. Nicel veriler için ortalama ve standart sapma (SS), nitel veriler için ise yüzde (\%) değerleri sunuldu. Verilerin dağılım normalliği, Onesample Kolmogorov Smirnov ve histogram değerlendirmeleri ile test edildi. İstatistiksel anlamlılık düzeyi $p<0,05$ olarak belirlendi. Bağımsız değişkenlerin bağımlı değişkenler ile ilişkisinin belirlenmesinde çoklu doğrusal regresyon analizi kullanıldı.

\section{SONUÇLAR}

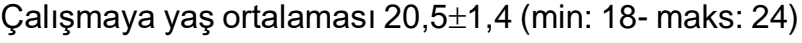
yıl, boy ortalaması 166,9 $\pm 8,0$ (min:150-maks:190) santimetre, vücut kitle indeksi (VKI) 21,4 $\pm 3,0 \mathrm{~kg} / \mathrm{cm} 2$ (min:16,2-maks:32,0) olan 273 gönüllü katılımcı dahil oldu. Katılımcılar \%84 kadın ( $n=229), \% 16$ erkek $(n=44)$ bireylerden oluşmaktaydı (Tablo 1 ).

Tablo 1. Katılımcıların demografik bilgileri.

\begin{tabular}{ccc}
\hline $\mathbf{( n = 2 7 3 )}$ & Ortalama $\pm \mathbf{S S}$. & Minimum- Maksimum \\
\hline Yaş & $20,5 \pm 1,4$ & $18-24$ \\
\hline Boy & $166,9 \pm 8,0$ & $2-31$ \\
\hline Vücut Kitle İndeksi & $21,3 \pm 2,9$ & $16,2-32,0$ \\
\hline Cinsiyet $\mathbf{n}(\%)$ & & K: $229(83,9), E: 44(16,1)$ \\
\hline
\end{tabular}

* SS: Standart sapma, n: Sayı, \%: Yüzde, K: Kadın, E: Erkek

Katılımcıların UFAA-KF skor ortalaması 964,1 1944,7 MET-dk/hafta (min:33- maks:4455) olarak kaydedildi. Fiziksel aktivite düzeylerine sınıflandırma yapıldığında, katılımcıların \%52,7'sinin (n:144) fiziksel olarak aktif olmadığı, \%42,5'inin (n:116) fiziksel aktivite düzeyinin düşük olduğu, \%4,8'inin (n: 13) yeterli fiziksel aktivite düzeyine sahip olduğu belirlendi. Katılımcıların BDÖ skor ortalaması 13,8 $\pm 6,4$ (min:2, maks:31) olarak kaydedildi. Katılımcıların \%33,7'sinde (n:92) minimal düzeyde, $\% 32,6$ 'sında (n:89) hafif düzeyde, \%28,2'sinde (n:77) orta düzeyde ve \%5,5'inde ciddi düzeyde depresyon varlığı belirlendi. Katılımcıların DSÖ-5 skor ortalaması 11,8 $\pm 5,1$ (min:1, maks: 25 ) olarak kaydedildi. Katılımcıların \%57,5’inde (n:157) düşük duygu durumu, \%42,5'inde (n:116) iyilik hali belirlendi. Katılımcıların PUKI skor ortalaması 4,2 $\pm 2,0$ (min:1- maks:10) olarak belirlendi. Katılımcıların \%25,3'ünde (n:69) kötü uyku kalitesi, $\% 74,7$ 'sinde iyi uyku kalitesi varlığı belirlendi. Katılımcıların ASÖ skor ortalaması 30,0 5,3 (min:11maks:43) olarak belirlendi. Katılımcıların \%19,8'inde (n:54) düşük stres düzeyi, \%80,2'sinde (n: 219) orta stres düzeyi, \%0'ında (n:0) yüksek stres düzeyi varlığı belirlendi (Tablo 2 ).

Tablo 2. Fiziksel aktivite, depresyon, algılanan stres düzeyi, uyku ve yaşam kalitesi ölçüm sonuçları.

\begin{tabular}{|c|c|c|c|c|}
\hline$(n=273)$ & Ort. \pm SS. & Min-Max & Ölçeklerin Alt Sınıfları & n (\%) \\
\hline \multirow[t]{3}{*}{ UFAA-KF } & $964,1 \pm 944,7$ & $33-4455$ & Fiziksel Olarak İnaktif & $144(52,7)$ \\
\hline & & & Fiziksel Aktivite Düzeyi Düşük & $116(42,5)$ \\
\hline & & & Fiziksel Aktivite Düzeyi Yeterli & $13(4,8)$ \\
\hline \multirow{4}{*}{ BDÖ } & $13,8 \pm 6,4$ & $2-31$ & Minimal Düzeyde & $92(33,7)$ \\
\hline & & & Hafif Düzeyde & $89(32,6)$ \\
\hline & & & Orta Düzeyde & $77(28,2)$ \\
\hline & & & Ciddi Düzeyde & $15(5,5)$ \\
\hline \multirow[t]{2}{*}{ PUKi } & $4,2 \pm 2,0$ & $1-10$ & Kötü Uyku Kalitesi & $69(25,3)$ \\
\hline & & & İyi Uyku Kalitesi & $204(74,7)$ \\
\hline \multirow[t]{3}{*}{ ASD } & $30,0 \pm 5,3$ & $11-43$ & Düşük Stres Düzeyi & $54(19,8)$ \\
\hline & & & Orta Stres Düzeyi & $219(80,2)$ \\
\hline & & & Yüksek Stres Düzeyi & $0(0,0)$ \\
\hline \multirow[t]{2}{*}{ DSÖ-5 } & $11,8 \pm 5,1$ & $1-25$ & Düşük Duygu Durumu & $157(57,5)$ \\
\hline & & & İyilik Hali & $116(42,5)$ \\
\hline
\end{tabular}

UFAA-KF: Uluslararası Fiziksel Aktivite Anketi- Kısa Form, BDÖ: Beck Depresyon Ölçeği, PUKi: Pittsburgh Uyku Kalite Indeksi, ASD: Algılanan Stres Düzeyi, DSÖ5: Dünya Sağlık Örgütü-5 lyilik Hali Endeksi, 
Katılımcıların fiziksel aktivite düzeyleri ile depresyon, yaşam kalitesi, uyku ve stres düzeyleri arasındaki ilişki değerlendirildi. Fiziksel aktivite düzeyi yeterli olan bireyler (n:13) sayıca yetersiz olduğu için bu değerlendirmeye dahil edilmedi. Fiziksel aktivite düzeyi düşük olan (n:116) katılımcılar ile fiziksel olarak aktif olmayan bireyler arasında yaşam ve uyku kalitesi açısından anlamlı fark bulundu $(p<0,05)$ (Tablo 3).

Tablo 3. Öğrencilerin fiziksel aktivite düzeyi ile depresyon, yaşam kalitesi, uyku ve stres ilişkisi.

\begin{tabular}{|c|c|c|c|c|}
\hline$(n=260)$ & UFAA-KF Sınıfı & $n(\%)$ & Ort. \pm SS. & $\mathbf{P}$ \\
\hline \multirow[t]{2}{*}{ BDÖ } & Fiziksel Olarak İnaktif & $144(55,4)$ & $13,9 \pm 6,5$ & \multirow[t]{2}{*}{0,494} \\
\hline & Fiziksel Aktivite Düzeyi Düşük Olan & $116(44,6)$ & $13,3 \pm 6,7$ & \\
\hline \multirow[t]{2}{*}{ PUKí } & Fiziksel Olarak İnaktif & $144(55,4)$ & $4,0 \pm 1,8$ & \multirow[t]{2}{*}{$0,035^{\star}$} \\
\hline & Fiziksel Aktivite Düzeyi Düşük Olan & $116(44,6)$ & $4,5 \pm 2,2$ & \\
\hline \multirow[t]{2}{*}{ ASD } & Fiziksel Olarak İnaktif & $144(55,4)$ & $29,7 \pm 5,3$ & \multirow[t]{2}{*}{0,426} \\
\hline & Fiziksel Aktivite Düzeyi Düşük Olan & $116(44,6)$ & $30,2 \pm 5,5$ & \\
\hline \multirow[t]{2}{*}{ DSÖ-5 } & Fiziksel Olarak İnaktif & $144(55,4)$ & $11,0 \pm 5,0$ & \multirow[t]{2}{*}{$0,008^{\star}$} \\
\hline & Fiziksel Aktivite Düzeyi Düşük Olan & $116(44,6)$ & $12,7 \pm 5,1$ & \\
\hline
\end{tabular}

* Istatistiksel anlamlılık düzeyi p<0,05 olarak kabul edilmiştir (Independent Sample T-Test). UFAA- KF: Uluslararası Fiziksel Aktivite Anketi- Kısa Form, BDÖ: Beck Depresyon Ölçeği, PUKi: Pittsburgh Uyku Kalite Indeksi, ASD: Algılanan Stres Düzeyi, DSÖ5: Dünya Sağlık Örgütü-5 lyilik Hali Endeksi, Ort: Ortalama, SS: Standart sapma

Fiziksel aktivite, depresyon, uyku kalitesi ve stres düzeylerinin yaşam kalitesine ilişkin çoklu regresyon analizi modeli anlamlı olarak belirlendi $(F=18,115$; $p=0,001 ; R 2=0,213)$. Regresyon modeli sonuçlarına göre, yaşam kalitesi ile fiziksel aktivite arasında pozitif yönlü anlamlı ilişki olduğu $(\beta=0,156, p=0,005$, $)$ yaşam kalitesi ile depresyon arasında negatif yönlü anlamlı ilişki olduğu $(\beta=-0,389, p=0,001)$ saptandı. Yaşam kalitesi ile uyku düzeyi $(\beta=-0,079, p=0,200)$ ve stres düzeyleri $(\beta=-0,071, p=0,195)$ arasında negatif yönlü ilişki olduğu belirlenirken regresyon modelinde anlamlı değildi (Tablo 4).

Tablo 4. Öğrencilerin yaşam kalitesi ile fiziksel aktivite, depresyon, uyku kalitesi ve stres düzeyleri arasında regresyon analizi.

\begin{tabular}{|c|c|c|c|c|c|c|c|c|c|}
\hline $\begin{array}{c}\text { Bağımlı Değişken } \\
\text { DSÖ-5 }\end{array}$ & B & Std. & $\beta$ & $t$ & $\mathbf{P}$ & $\mathbf{R}$ & $\mathbf{R}^{2}$ & $\mathbf{F}$ & $\mathbf{P}$ \\
\hline UFAA-KF & 1,356 & 0,474 & 0,156 & 2,860 & $0,005^{*}$ & 0,461 & 0,213 & 18,115 & $0,001^{*}$ \\
\hline BDÖ & $-0,300$ & 0,047 & $-0,389$ & $-6,391$ & $0,001^{*}$ & & & & \\
\hline PUKi & $-0,207$ & 0,161 & $-0,079$ & $-1,283$ & 0,200 & & & & \\
\hline ASD & $-0,069$ & 0,053 & $-0,071$ & $-1,298$ & 0,195 & & & & \\
\hline
\end{tabular}

* Istatistiksel anlamlılık düzeyi p<0,05 olarak kabul edilmiştir (Basit Doğrusal Regresyon Analizi). UFAA- KF: Uluslararası Fiziksel Aktivite AnketiKısa Form, BDÖ: Beck Depresyon Ölçeği, PUKi: Pittsburgh Uyku Kalite Indeksi, ASD: Algılanan Stres Düzeyi, DSÖ5: Dünya Sağlık Örgütü-5 lyilik Hali Endeksi, Std: Standart sapma

\section{TARTIŞMA}

Çalışmamızda öncelikle Covid-19 pandemisi sırasında genç yetişkinlerin fiziksel aktivite, stres, uyku ve yaşam kalitesi düzeyleri araştırıldı. Çalışmanın en önemli bulgularından biri katılımcıların pandemi sırasındaki fiziksel aktivite düzeyleri ile ilgiliydi. Çalışmaya katılanların büyük çoğunluğu fiziksel olarak inaktifti $(\% 52,7)$ veya fiziksel aktivite düzeyleri $(\% 42,5)$ düşüktü. Böylelikle katılımcıların \%95,2'si yeterli fiziksel aktivite seviyesine sahip değildi. Fiziksel olarak inaktif olan bireyler, düşük fiziksel aktivite düzeyine sahip olanlara göre anlamlı olarak daha düşük yaşam kalitesine sahip iken uyku kaliteleri daha iyi olduğu tespit edildi. Bu dönem içerisinde katılımcıların yaklaşık \%75'inin uyku kaliteleri iyi, \%80 'inin stres algıları orta düzeydeydi. Katılımcıların yaklaşık \%66'sı minimal ve hafif düzeyde depresyona sahipti. Tüm bunlarla birlikte çalışmaya katılan genç yetişkinlerin \%57,7'si kötü yaşam kalitesi sonuçları bildirdi.

Literatürde genç yetişkin olan üniversite öğrencilerinde fiziksel aktivite düzeyleri ve ilişkili faktörlerin incelendiği çeşitli çalışmalar mevcuttur 
(Barğı ve ark., 2021; Bulguroğlu ve ark., 2021; Cihan ve Pirinççi, 2020; Demirer ve Erol, 2020). Çocukluk çağı başta olmak üzere üniversite çağındaki bireylerin fiziksel olarak aktif bireyler olmasının ilerleyen yaşlarda sağlık ile ilgili faydalar sağlaması açısından kritik öneme sahip olduğu gösterilmiştir (Fernandes ve Zanesco, 2010). Pandemi öncesi ülkemizde yapılan çalışmalarda üniversite öğrencilerindeki fiziksel aktivite yetersizliği birçok kez gözler önüne serilmiştir (Demirer ve Erol, 2020). Erol ve arkadaşlarının 702 üniversite öğrencisi ile UFAA kullanarak yaptıkları değerlendirmelere göre çalışmalarına katılan öğrencilerin \%20,4'ünün inaktif, \%57'sinin minimal aktif ve \%22,6'sının yeterince aktif düzeyde olduğunu göstermişlerdir (Demirer ve Erol, 2020). Üniversite öğrencilerinde halihazırda yetersiz olan fiziksel aktivite düzeylerinde pandemi ile beklenen düşüş bazı araştırmacılar tarafından kanıtlanmıştır. Ercan ve Keklicek'in (2020) 446 üniversite öğrencisi ile pandemi döneminde yaptıkları çalışmada öğrencilerde düzenli fiziksel aktivite yapma oranının azaldığı ve fiziksel inaktivite oranının arttığı bulunmuştur. Koca ve Fazlıoğluları'nın (2021) Covid-19 pandemi sürecinin gençlerin fiziksel aktivite sürelerine olan etkisini araştırdıkları çalışmada, günlük yürüyüş ve orta düzey fiziksel aktivitede geçirilen sürelerin azalırken, yatarak ve oturarak geçirilen ortalama sürenin ise arttığı bildirilmiştir. Başka bir çalışmada Bulguroğlu ve arkadaşları (2021) $\% 30,7$ oranında gençlerin fiziksel olarak inaktif olduğunu tespit etmişlerdir. Aynı çalışmada pandemi öncesinde $\% 32,53$ oranında düzenli fiziksel aktivite yapan gençlerin \%94,4'ünün pandemi ile birlikte fiziksel aktivitelerinin olumsuz yönde etkilendiği gösterilmiştir (Bulguroğlu ve ark., 2021). Barğı ve arkadaşlarının çalışmasında \%31,7 öğrenci inaktif, \%40,9 öğrenci minimal aktif ve \%27,4 öğrenci çok aktifti (Barğı ve ark., 2021). Çalışmamızda ise katıııcılardan yarısından fazlası (yaklaşık \%53) pandemi süresince fiziksel olarak inaktif olduklarını beyan etti. Dahası sadece $\% 4,8$ 'inin fiziksel aktivite düzeyi yeterli sınırlarda idi. Bizim çalışmamızın literatürdeki benzer çalışmalara göre fiziksel aktivite açısından daha olumsuz olan sonuçları çalışmaya katılan gençlerin ikamet ettiği illerdeki kısıtlama ve fiziksel aktivite olanaklarına ulaşım farklılıklarına bağlı olabileceği düşünülmektedir. Bu konuyla ilişkili olarak pandemi döneminde sokağa çıkma sınırlaması olan ve olmayan illerde yaşayan öğrencilerin fiziksel aktivite düzeylerinin UFAA-KF kullanarak araştıııldığı bir çalışmada sokağa çıkma yasağı olan illerde yaşayan öğrencilerin fiziksel aktivite düzeylerinin olmayanlara göre anlamlı olarak düşük bulunduğu rapor edilmiştir (Öncen, Aydın ve Molla, 2020). Konu ile ilgili yapılması planlanan diğer çalışmalarda bu durum göz önünde bulundurularak değerlendirmelere dahil edilmesi önerilmektedir.

Pandemi döneminde üniversite öğrencilerinde etkilenmiş olabileceği düşünülen sağlık ile ilişkili bir diğer parametre uyku kalitesidir. Pandemi öncesi çalışmalarda da üniversite öğrencilerinin yetersiz uyuduğu ve kötü uyku kalitesine sahip oldukları yönünde bir görüş hakimdir (liyigün ve ark., 2017; Orzech, Salafsky ve Hamilton, 2011). Ülkemizde yapılan çalışmada üniversite öğrencilerinin yaklaşık yarısından fazlasının uyku kalitesinin kötü olduğu tespit edilerek bu görüş desteklenmiştir (Mayda, Kasap, Yıldırım ve ark., 2012). Amerika Birleşik Devletleri'nde 631 öğrencinin dahil edildiği çalışmada ise pandemi döneminde iyi uyku kalitesine sahip olan öğrencilerin oranı yaklaşık \%58 olarak kaydedilmiştir (Ulrich, Full, Cheng ve ark., 2021). Çalışmamızda aynı ölçek ile ölçülen uyku kalitesi, katılımcıların \%25,3'ünde kötü olarak bulunmuştur. Ayrıca çalışmamızda inaktif gençler ile fiziksel aktivite seviyesi düşük olan gençlerin uyku kaliteleri karşılaştırıldığında inaktif olan gençlerin uyku kalitelerinin, düşük aktivite seviyesine sahip öğrencilere göre daha iyi olduğu belirlenmiştir. Her iki grubun ortalama skorlarına bakıldığında uyku kalitelerinin iyi sınıflamasına ait olduğu söylenebilir. Koca ve Fazlığluları'nın (2021) üniversite öğrencileri ile yaptıkları bir çalışmada pandemi öncesine göre gençlerin pandemi süresince anlamlı derecede daha fazla uyudukları bildirilmiştir. Çalışmamıza katılan genç yetişkinlerin aktivite, dinlenme, oturarak vakit geçirme ve uyuma süreleri gibi günlük yaşam alışkanlıkları sorulmadı. Uyku süresinin artması fiziksel olarak inaktif geçirilen sürenin artmasına sebep olabilir. Fiziksel aktivite düzeyi yeterli olan gençleri de dahil ederek yapılacak ileri çalışmalar ile fiziksel aktivite ve uyku kalitesi arasındaki ilişki detaylı araştııımalıdır. Çünkü iyi bir uyku kalitesi fizyolojik ve psikolojik sağlık ile yakından ilişkilidir (Şenol, Soyuer, Akça ve ark., 2012).

Pandemi döneminde özellikle etkileneceği düşünülen ve sağlıklı olma tanımı içerisinde yer alan psikolojik faktörlerin de dahil edilmesi için çalışmamızda genç yetişkinlerin depresyon ve stres algısı düzeyleri incelenmiştir. Bulguroğlu ve arkadaşları (2021) pandemi döneminde 332 üniversite öğrencileri ile yaptıkları çalışmalarında Beck Depresyon Ölçeğini kullanmışlar ve ortalama olarak 16.03 skorunu (Beck Depresyon Ölçeği: 10-16 puan hafif düzeyde depresyon; 17-29 orta düzeyde depresyon) 
kaydetmişlerdir. Çalışmalarına katılan öğrencilerin pandemi döneminde hafif-orta düzey depresyon sınıflamasında yer aldığı görülmektedir (Bulguroğlu ve ark., 2021). Bayar, Can, Erten ve arkadaşlarının (2021) 565 öğrenci katılımı ile elde ettiği sonuçlara göre çalışmalarına katılan öğrenciler pandemi döneminde ortalama 21,41 puan ile orta düzey depresyona sahipti. Yine aynı çalışmada öğrenciler 31,81 puan ortalaması ile orta düzey stres algısı rapor etmişlerdir. Çalışmamızın algılanan stres ölçeği sonuçları (ASÖ: ortalama 30.0) ile Bayar ve arkadaşlarının (2021) sonuçları paraleldi. Cihan ve Pirinççi'nin (2020) çalışmasına katılan gençlerin depresyon ölçeği skoru ortalama 13.47 ile çalışmamızla (BDÖ ortalama: 13.8) oldukça benzerdi. Tuğut ve arkadaşlarının (2021) pandemi döneminde sağlık alanında farklı disiplinlerde okuyan üniversite öğrencileri ile yaptıkları çalışmada diş hekimi öğrencileri orta düzey depresif bulunurken hemşirelik, diş protez teknolojisi ve ağız diş sağlığı öğrencileri hafif düzey depresyona sahipti. Ayrıca aynı çalışmada diş hekimliğinde okuyan öğrencilerin algılanan stres düzeyleri diğer bölümlerde okuyan öğrencilere göre daha yüksek olduğu belirtilmiştir (Tuğut ve ark., 2021). Pandemi döneminde üniversite öğrencilerinin dahil olduğu ve özelikle psikolojik faktörleri içeren çalışmaların sonuçları literatürle tartışırken öğrencilerin öğrenim gördüğü bölümler dikkate alınabilir. Literatürde üniversitede öğrenim gören öğrencilerin fiziksel aktivite seviyelerinin depresyon düzeyleri ile ilişkili olduğunu belirten çalışmalar vardır (Gerber ve ark., 2014; Tekin ve ark., 2009). Pandemi döneminde yapılan çalışmamızın sonuçlarına göre fiziksel olarak aktif olmayan katılımcılar ile fiziksel aktivite düzeyi düşük olan katılımcılar arasında depresyon ve algılanan stres düzeyi arasında bir fark bulunmamış olup her iki gruptaki öğrenciler hafif düzey depresyon ve orta düzey stres algısına sahipti.

Pandemi öncesinde olduğu gibi pandemi döneminde de üniversite öğrencilerinin yaşam kalitesi ve yaşam kalitesine etki eden faktörler önemli bir araştırma konusu olmuştur. Hem ülkemizde hem de diğer ülkelerde üniversite öğrencilerinde pandemi öncesi yapılan fiziksel aktivite ve yaşam kalitesi ile ilgili çalışmalar iki parametre arasındaki ilişkiyi göstermiştir (Gerber ve ark., 2014; Tekin ve ark., 2009). Bu çalışmalar üniversite öğrencilerinde fiziksel aktivite seviyelerindeki artışın yaşam kalitesi skorlarını artırdığını göstermiştir (Gerber ve ark., 2014; Tekin ve ark., 2009). Pandemi döneminde yapılan çalışmamızda, daha önce tartışılan sağlık ile ilişkili faktörlerden fiziksel aktivite, depresyon, stres düzeyleri ve uyku kalitesinin üniversite öğrencilerinde yaşam kalitesini nasıl etkilediği ayrıca araştırıldı. Araştırmamız, regresyon analizi sonuçlarına göre, yaşam kalitesi ile fiziksel aktivite arasında pozitif yönlü anlamlı ilişki olduğu $(\beta=0,156, p=0,005$, ) yaşam kalitesi ile depresyon arasında negatif yönlü anlamlı ilişki olduğu ( $\beta=-0,389, p=0,001)$ saptandı. Yaşam kalitesi ile uyku düzeyi $(\beta=-0,079, p=0,200)$ ve stres düzeyleri $(\beta=-$ $0,071, p=0,195)$ arasında negatif yönlü ilişki olduğu belirlenirken regresyon modeline göre anlamlı olmadığı belirlendi. Bulguroğlu ve arkadaşlarının (2021) pandemi döneminde yaptıkları benzer bir çalışmada fiziksel aktivite ve depresyon düzeyleri yaşam kalitesi ile ilişkili bulunmuştur (Bulguroğlu ve ark., 2021). Peru'da pandemi dönemi üniversite öğrencilerinde yaşam kalitesi ve depresif semptomları araştıran bir çalışmanın sonuçlarına göre yaşam kalitesini en çok etkileyen boyut anksiyete ve depresyon olarak kaydedilmiştir (Figueroa-Quiñones, Ipanaqué-Zapata, Machay-Pak ve ark., 2020). Yine benzer konuda ülkemizde yapılan bir çalışmada ise fiziksel aktivite ortalama adım sayısı, depresyon düzeyi BDÖ ve yaşam kalitesi SF-36 Kısa Form ile değerlendirilmiş ve yaşam kalitesi ile adım sayısı arasında bir ilişkiye rastlanmazken depresyon düzeyi ile bir ilişki bulunmuştur (Cihan ve Pirinççi, 2020).

Literatüre bakıldığında çalışmaların büyük çoğunluğu bizim çalışmamızla benzer şekilde durum tespiti için dizayn edilmiş kesitsel tipte çalışmalardır. Çalışmamızın sonuçları ile birlikte literatürdeki çalışmaların sonuçlarına bakıldığında pandeminin, genç yetişkinlerin hem fiziksel ve hem de mental olarak yaşamlarını etkileyen bir süreç olduğu görülmektedir. Çalışmanın limitasyonlarından biri yaşam kalitesi ile ilişkili olduğu düşünülen ve çalışmamızda sorgulanan parametrelerin pandemi dönemi öncesi verilerinin bulunmayışıdır. Üniversite öğrencileri ile planlanmış pandemi dönemi öncesi verilerini de içeren karşılaştırmalı çalışmalar pandeminin fiziksel aktivite, depresyon, stres algısı düzeyleri, uyku ve yaşam kalitesi üzerine bu olumsuz etkisinin pekiştirilmesi için fayda sağlayacaktır.

Üniversite öğrencilerinin Covid-19 pandemi döneminde fiziksel aktivite, stres, uyku ve yaşam kalitesi düzeylerinin incelendiği araştırmamız katılımcılarının \%95,2'sinin $(n=260)$ yetersiz fiziksel aktivite düzeyine sahip olduğu tespit edildi. Fiziksel olarak inaktif olan öğrencilerin, fiziksel aktivite düzeyi düşük olanlara göre anlamlı olarak daha düşük yaşam 
kalitesine sahip olduğu belirlendi. Araştırmaya katılan öğrencilerin yaklaşık \%75'inin ( $n=204)$ uyku kalitelerinin iyi, ancak \%80 'inin $(n=219)$ stres algılarının orta düzeyde olduğu tespit edildi. Öğrencilerin yaklaşık \%66'sının minimal ve hafif düzeyde depresyona sahip oldukları belirlendi. Ayrıca, araştırmaya katılan üniversite öğrencilerinin \%57,7'si (n=157) DSÖ-5 iyilik hali endeksine göre düşük duygu durumu bildirdi.

Araştırmamızda regresyon modeli sonuçlarımıza göre genç yetişkinlerde Covid-19 pandemi sürecinde fiziksel aktivite, depresyon, uyku ve stres düzeylerinin yaşam kalitesi üzerine etkisinin olduğu belirlendi. Modelde fiziksel aktivite düzeyindeki artış yaşam kalitesini yükseltirken, depresyon düzeyindeki artışın yaşam kalitesini düşürdüğü bulundu. Regresyon modeli sonuçlarına göre uyku ve stres düzeylerinin yaşam kalitesi üzerinde etkili olduğu, bu etkinin doğrusal olmadığı sonucu çıkarılabilir. Sonuçlarımıza göre Covid-19 pandemi süresinde genç yetişkinlerde toplum sağlığını korumaya yönelik planlamalarda fiziksel aktivite düzeyinin ve uyku kalitesinin arttırılmasına yönelik stratejilerin oluşturulması, mental sağlığın korunması ve stresin düzeylerinin azaltılmasına yönelik desteklerin teşvik edilmesi gerektiği düşünülmektedir

\section{Etik Onay}

Çalışma için 2021/92 protokol numarası ile Marmara Üniversitesi Sağlık Bilimleri Fakültesi Girişimsel Olmayan Klinik Araştırmalar Etik Kurulu Başkanlığı'ndan etik onayı alındı. Ayrıca çalışmada kullanılacak anketler için ilgili anketin Türkçe geçerlik güvenirlik çalışmasını yapan anket geliştiricilerden e-posta yoluyla izin talep edildi.

\section{Araştırmacıların Katkı Oranı}

ET: Fikir/kavram, tasarım, kaynak taraması, makalenin yazımı;

EEA: Kaynak taraması, makalenin yazımı, tasarım; BA: Kaynak taraması, makalenin yazımı, tasarım; ID: Fikir/kavram, tasarım, makalenin yazımı, denetleme/danışmanlık;

MGP: Denetleme/danışmanlık, eleştirel inceleme, malzemeler, tasarım

\section{Çıkar Çatışması Beyanı}

Tüm yazarlar, araştırma ile ilgili çıkar çatışması olmadığını beyan etmektedir.

\section{Destek/Teşekkür}

Finansal destek yoktur. Teşekkür açıklaması yoktur.

\section{Kaynaklar}

Ağargün, M., Kara, H., Anlar, O. (1996). Pittsburgh uyku kalitesi indeksinin gecerliği ve güvenirliği. Türk Psikiyatri Dergisi, 7(2), 107-115.

Barğı, G., Şahin, E., \& Çimenli, Ç. (2021). Covid-19 pandemisi sebebi ile uzaktan eğitim gören üniversite öğrencilerinde stres, anksiyete, depresyon ve fiziksel aktivite düzeylerinin incelenmesi. Izmir Democracy University Health Sciences Journal, $\quad 4(2)$ 159-168. https://doi.org/10.52538/iduhes.941379

Bayar, B. D., Can, S. Y., Erten, M., \& Ekmen, M. (2021). Covid19 pandemi sürecinde üniversite öğrencilerinin depresyon ve stres düzeylerinin belirlenmesi. Paramedik ve Acil Sağlık Hizmetleri Dergisi, 2(1), 12-25.

Beck, A. T., Ward, C., Mendelson, M., Mock, J., \& Erbaugh, J. (1961). Beck depression inventory (BDI). Arch Gen Psychiatry, 4(6), 561-571.

Bulguroğlu, H. I., Bulguroğlu, M., \& Özaslan, A. (2021). Covid-19 pandemi sürecinde üniversite öğrencilerinin fiziksel aktivite, yaşam kalitesi ve depresyon seviyelerinin incelenmesi. Acıbadem Üniversitesi Sağlık Bilimleri Dergisi, 12(2), 306311. https://doi.org/10.31067/acusaglik. 852175

Buysse, D. J., Reynolds, C. F., Monk, T. H., Berman, S. R., \& Kupfer, D. J. (1989). The Pittsburgh Sleep Quality Index: a new instrument for psychiatric practice and research. Psychiatry Res, 28(2), 193-213. https://doi.org/10.1016/0165-1781(89)90047-4

Cihan, E., \& Pirinççi, C. Ş. (2020). Covid-19 pandemi sürecinde genç popülasyonun yaşam kalitesinin fiziksel aktivite seviyesi ve depresyon düzeyi ile ilişkisi. Selçuk Sağlık Dergisi, 1(covid-19 özel), 41-53.

Cohen, S., Kamarck, T., \& Mermelstein, R. (1983). A global measure of perceived stress. J Health Soc Behav, 24(4), 385-396. https://doi.org/10.2307/2136404

Craig, C. L., Marshall, A. L., Sjostrom, M., Bauman, A. E., Booth, M. L., Ainsworth, B. E., et al. (2003). International physical activity questionnaire: 12 -country reliability and validity. Med Sci Sports Exerc, 35(8), 1381-1395. https://doi.org/10.1249/01.MSS.0000078924.61453.FB

Demirer, İ., \& Erol, S. (2020). Üniversite öğrencilerinin fiziksel aktivite düzeyleri ile uykusuzluk ve psikolojik iyilikleri arasındaki ilişki. Psikiyatri Hemşireliği Dergisi, 11(3), 201211. https://doi.org/10.14744/phd.2020.46547

DeSalvo, K. B., Bloser, N., Reynolds, K., He, J., \& Muntner, P. (2006). Mortality prediction with a single general self-rated health question. A meta-analysis. J Gen Intern Med, 21(3), 267-275. https://doi.org/10.1111/j.1525-1497.2005.00291.x

Ellis, W. E., Dumas, T. M., \& Forbes, L. M. (2020). Physically isolated but socially connected: psychological adjustment and stress among adolescents during the initial COVID-19 crisis. Canadian Journal of Behavioural Science, 52(3), 177187. https://doi.org/10.1037/cbs0000215

Ercan, Ş., \& Keklicek, H. (2020). COVID-19 pandemisi nedeniyle üniversite öğrencilerinin fiziksel aktivite düzeylerindeki değişimin incelenmesi. İzmir Katip Çelebi Üniversitesi Sağlık Bilimleri Fakültesi Dergisi, 5(2), 69-74.

Erdoğan Yüce, G., \& Muz, G. (2021). COVID-19 pandemisinin yetişkinlerin diyet davranışları, fiziksel aktivite ve stres düzeyleri üzerine etkisi. Cukurova Medical Journal, 46(1), 283-291. https://doi.org/10.17826/cumj.794585 
Eser, E., Çevik, C., Baydur, H., Güneş, S., Esgin, T. A., Öztekin, Ç., et al. (2019). Reliability and validity of the Turkish version of the WHO-5, in adults and older adults for its use in primary care settings. Prim Health Care Res Dev, 20, E100. doi:10.1017/S1463423619000343

Eskin, M., Harlak, H., Demirkıran, F., \& Dereboy, Ç. (2013). Algılanan stres ölçeğinin Türkçeye uyarlanması: güvenirlik ve geçerlik analizi. New/Yeni Symposium Journal, 51(3), 132-140.

Fazeli, S., Zeidi, I. M., Lin, C. Y., Namdar, P., Griffiths, M. D., Ahorsu, D. K., et al. (2020). Depression, anxiety, and stress mediate the associations between internet gaming disorder, insomnia, and quality of life during the COVID-19 outbreak. Addict Behav, 12, 100307. https://doi.org/10.1016/j.abrep.2020.100307

Fernandes, R. A., \& Zanesco, A. (2010). Early physical activity promotes lower prevalence of chronic diseases in adulthood. Hypertens Res, 33(9), 926-931. https://doi.org/10.1038/hr.2010.106

Figueroa-Quiñones, J., Ipanaqué-Zapata, M., Machay-Pak, D., \& Rodriguez-Ruiz, J. (2020). Quality of life and depressive symptoms among Peruvian university students during the COVID-19 pandemic.Preprint. bioRxiv. https://doi.org/10.1101/2020.12.04.411330

Gerber, M., Brand, S., Elliot, C., Holsboer-Trachsler, E., \& Pühse, U. (2014). Aerobic exercise, ball sports, dancing, and weight lifting as moderators of the relationship between stress and depressive symptoms: an exploratory cross-sectional study with swiss university students. Percep Mot Skills, 119(3), 679697. https://doi.org/10.2466/06.PMS.119c26z4

Hisli, N. (1989). Beck depresyon envanterinin üniversite öğrencileri için geçerliliği, güvenilirliği. J Physiocol, 7(23), 3-13.

Huang, C., Wang, Y., Li, X., Ren, L., Zhao, J., Hu, Y., ve ark. (2020). Clinical features of patients infected with 2019 novel coronavirus in Wuhan, China. Lancet, 395(10223), 497-506. https://doi.org/10.1016/S01406736(20)30183-5

İyigün, G., Angın, E., Kırmızıgil, B., Öksüz, S., Özdil, A., \& Malkoç, M. (2017). Üniversite öğrencilerinde uyku kalitesinin mental sağlık, fiziksel sağlık ve yaşam kalitesi ile ilişkisi. JETR, 4(3), 125-133. https://dergipark.org.tr/en/pub/jetr/issue/41952/50554

Koca, R., \& Fazlıoğluları, Z. (2021). Covid 19 pandemi sürecinin gençlerin fiziksel aktivite sürelerine olan etkisinin araştıııması. Genel Tıp Dergisi, 31(2), 153158. https://doi.org/10.15321/GenelTipDer.2021.304

Lipert, A., Kozłowski, R., Timler, D., Marczak, M., Musiał, K., Rasmus, P., et al. (2021). Physical activity as a predictor of the level of stress and quality of sleep during COVID-19 lockdown. Int J Envron, 18(11), 5811. https://doi.org/10.3390/ijerph18115811

Mayda, A., Kasap, H., Yıldırım, C., Yılmaz, M., Derdiyok, Ç., Ertan, D., et al. (2012). 4-5-6. sınıf tıp fakültesi öğrencilerinde uyku bozukluğu sıklığı. Düzce Üniversitesi Sağlık Bilimleri Enstitüsü Dergisi, 2(2), 811.

https://dergipark.org.tr/en/pub/duzcesbed/issue/4840/ 66577

Moriarty, T., Bourbeau, K., Fontana, F., McNamara, S., \&
Pereira da Silva, M. (2021). The relationship between psychological stress and healthy lifestyle behaviors during COVID-19 among students in a US Midwest University. Int $J$ Envron, 18(9), 4752. https://doi.org/10.3390/ijerph18094752

Öncen, S., Aydın, S., \& Molla, E. (2020). COVID-19 pandemisi döneminde sokağa çıkma sınırlaması olan ve olmayan illerde yaşayan spor bilimleri öğrencilerinin fiziksel aktivite düzeylerinin değerlendirilmesi. Electronic Turkish Studies, 15(6), 739-749. http://dx.doi.org/10.7827/TurkishStudies.44627

Orzech, K. M., Salafsky, D. B., \& Hamilton, L. A. (2011). The state of sleep among college students at a large public university. J Am Coll Health, 59(7), 612-619. https://doi.org/10.1080/07448481.2010.520051

Öztürk, M. (2005). Üniversitede eğitim-öğretim gören öğrencilerde uluslararası fiziksel aktivite anketinin geçerliliği ve güvenirliği ve fiziksel aktivite düzeylerinin belirlenmesi (Yüksek lisans tezi). Hacettepe Üniversitesi Sağlık Bilimleri Enstitüsü, Ankara.

Pace, B. (2000). The benefits of regular physical activity. JAMA, 283(22), 3030. https://doi.org/10.1001/jama.283.22.3030

Rogowska, A. M., Kusnierz, C., \& Bokszczanin, A. (2020). Examining anxiety, life satisfaction, general health, stress and coping styles during COVID-19 pandemic in Polish sample of university students. Psychol Res Behav Manag, 28(13), 797-811. https://doi.org/10.2147/PRBM.S266511

Rogowska, A. M., Pavlova, I., Kuśnierz, C., Ochnik, D., Bodnar, I., \& Petrytsa, P. (2020). Does physical activity matter for the mental health of university students during the COVID-19 pandemic? J Clin Med, 9(11), 3494. https://doi.org/10.3390/jcm9113494

Salari, N., Hosseinian-Far, A., Jalali, R., Vaisi-Raygani, A., Rasoulpoor, S., Mohammadi, et al. (2020). Prevalence of stress, anxiety, depression among the general population during the COVID-19 pandemic: a systematic review and meta-analysis. Glob Health, 16(1), 1-11. https://doi.org/10.1186/s12992-020-00589-w

Şenol, V., Soyuer, F., Akça, R. P., \& Argün, M. (2012). Adolesanlarda uyku kalitesi ve etkileyen faktörler. Kocatepe Tıp Dergisi, 13(2), 93-104.

Stanton, R., To, Q. G., Khalesi, S., Williams, S. L., Alley, S. J., Thwaite, T. L., et al. (2020). Depression, anxiety and stress during COVID-19: associations with changes in physical activity, sleep, tobacco and alcohol use in Australian adults. Int J Envron, 17(11), 4065. https://doi.org/10.3390/ijerph17114065

Tekin, G., Amman, M. T., \& Tekin, A. (2009). Serbest zamanlarda yapılan fiziksel egzersizin üniversite öğrencilerinin depresyon ve atılganlık düzeylerine etkisi. Uluslararası Insan Bilimleri Dergisi, 6(2), 148-159.

Tobaiqy, M., Qashqary, M., Al-Dahery, S., Mujallad, A., Hershan, A. A., Kamal, M. A., et al. (2020). Therapeutic management of patients with COVID-19: a systematic review. Infect Prev Pract, 2 2(3), 100061. https://doi.org/10.1016/j.infpip.2020.100061

Tuğut, F., Tuğut, N., \& Çelik, B. Y. (2021). Sağlık alanında okuyan öğrencilerin Covid-19 pandemi sürecinde durumluk süreklilik kaygı, algılanan stres ve depresyon düzeylerinin belirlenmesi. Cumhuriyet Üniversitesi Sağılk Bilimleri Enstitüsü $\quad$ Dergisi, $\quad$ 6(2), 136-144. https://doi.org/10.51754/cusbed.889349

Ulrich, A. K., Full, K. M., Cheng, B., Gravagna, K., Nederhoff, D., \& Basta, N. E. (2021). Stress, anxiety, and sleep among 
college and university students during the COVID-19

pandemic. J Am Coll Health, 1-5.

https://doi.org/10.1080/07448481.2021.1928143

Violant-Holz, V., Gallego-Jimenez, M. G., Gonzalez-

Gonzalez, C. S., Munoz-Violant, S., Rodriguez, M. J.,

Sansano-Nadal, O., et al. (2020). Psychological health and physical activity levels during the COVID-19 pandemic: a systematic review. Int $J$ Environ Res
Public
Health,
17(24),
9419.

https://doi.org/10.3390/ijerph17249419 